\title{
Hazard quotient, microbial diversity, and plant composition of spent crude oil- polluted soil
}

\author{
Beckley Ikhajiagbe ${ }^{1}$ and Matthew Chidozie Ogwu ${ }^{1,2^{*}}$ (D)
}

\begin{abstract}
Background: The present work assesses the concentration of some heavy metal, plant species composition, and microbial diversity of spent crude oil-polluted soil from electric generator plant house, auto mechanic workshop, bakery, and auto spare part shops in four local governments areas (Egor, Ikpoba-Okha, Oredo, and Ovia North) in Edo State, Southern Nigeria.

Results: Hazard quotient (HQ) of heavy metals varied in all the spent crude oil-polluted soil evaluated in the study. The HQ of heavy metals from auto mechanic workshop had the highest values for $\mathrm{Cr}$ (2.19), Mn (0.0965), Zn (4.1108), Fe (9.32015), and $\mathrm{Cd}(0.0155)$. The most frequent bacterial and fungal species found in all 16 sites were Bacillus subtilis (93.75\%) and Aspergillus niger (100.0\%) respectively. Auto spare part shops in Oredo had a bacterial count of $1.0 \times 10^{5} \mathrm{CFU} / \mathrm{g}$ while the bacteria count around power generator plants in Egor had a bacteria count of $1.71 \times 10^{5} \mathrm{CFU} / \mathrm{g}$. Some of the plant species identified around all the sites include Acanthospermum hispidum, Alternanthera repens, Axonopus compressus, Cyperus esculentus, Eleusine indica, Paspalum scrobiculatum, and Tridax procumbens.
\end{abstract}

Conclusion: Spent crude oil pollution of the soil led to high amounts of heavy metal in the soil. However, the presence of higher plants and variable diversity and richness of microorganisms found in the soil are likely contributing to the remediation of the polluted soil.

Keywords: Spent crude oil, Soil pollution, Microbial diversity, Hazard quotient, Heavy metals

\section{Background}

The reliance on fossil fuel to meet our energy need continue to exacerbate among other issues oil pollution due to spillage, threat to environmental integrity, and biodiversity loss $[18,20,21,25,26]$. Oil spills at auto mechanic workshops, electric power-generating plants, and small- and large-scale industries continued to receive insufficient research attention despite the potential for accumulation and negative effects on sustainable development. Improper disposal of spent crude oil products increases the environmental

\footnotetext{
*Correspondence: matthew.ogwu@uniben.edu

'Department of Plant Biology and Biotechnology, Faculty of Life Science, University of Benin, PMB 1154, Ugbowo, Benin City, Edo State, Nigeria ${ }^{2}$ School of Bioscience and Veterinary Medicine, University of Camerino Center for Floristic Research of the Apennine, Gran Sasso and Monti della Laga National Park, San Colombo, 67021 Barisciano, L'Aquila, Italy
}

concentrations of heavy metals, which can in turn seep into the water table and contaminate groundwater [1, 14, 31]. Moreover, spent motor oil is a danger to the environment and constitutes a potential threat to human well-being and biodiversity [19]. Hydrocarbon in crude oil has the potential to be immobilized in the soil because they spread horizontally where they complicate abiotic and biotic interactions and chemical properties of the soil $[4,5,22]$.

Spent oil refers to used oils, e.g., waste oil removed from combustion engines [19]. Prior to use, engine oil consists of 80-90\% hydrocarbons while performance-enhancing additives make up the rest. However, the chemical composition of engine oils are altered during use through the breakdown of additives, contamination by foreign materials, combustion, and the addition of metals from the wear and tear. The new composition comprises of diverse hydrocarbons and heavy

\section{Springer Open}

( ) The Author(s). 2020 Open Access This article is licensed under a Creative Commons Attribution 4.0 International License, which permits use, sharing, adaptation, distribution and reproduction in any medium or format, as long as you give appropriate credit to the original author(s) and the source, provide a link to the Creative Commons licence, and indicate if changes were made. The images or other third party material in this article are included in the article's Creative Commons licence, unless indicated otherwise in a credit line to the material. If material is not included in the article's Creative Commons licence and your intended use is not permitted by statutory regulation or exceeds the permitted use, you will need to obtain permission directly from the copyright holder. To view a copy of this licence, visit http://creativecommons.org/licenses/by/4.0/. 
metals with high toxic potential to the different environment components [30]. Spent crude oil find their way to the environment from broken-down automobiles engines, electric power generators, and heavy-duty industrial machines where they impact ecosystem process, functions, and systems [22, 32].

This work aims to assess the ecological hazard quotient of heavy metals, plant species composition, and microbial diversity of different spent crude oil-polluted soils from Benin City, Southern Nigeria. The findings will contribute towards understanding the ecological hazards and toxicity levels of the heavy metals as well as the potential economic implications. The study will also document plant species found growing on these contaminated soils, which can be further investigated for their phytoremediation potentials.

\section{Methods}

This study area is four local government areas (Ikpoba Okha, Ovia North East, Egor, and Oredo) within Benin City, Southern Nigeria. The area is characterized by a hot humid climate with two distinct seasons of wet and dry.

Biased sampling was adopted to select areas within the study area where spent crude oil are commonly found on the ground, due to activities of either auto mechanics, parked vehicles, stationary industrial diesel engines, or oil dumpsites. Included in this study are soil from auto mechanic workshops (MW), bakeries (BK), generating plant houses (GN), and auto spare part dealer shops (SP). Prior to collecting soil samples, field reconnaissance studies was carried out to estimate the extent of pollution, level of soil contamination using the presence and absence of some flora and fauna, and developmental defects on some flora. Based on field reconnaissance, soil samples were collected from the following popular destinations:

1. Egor local government area-Benzito Fast Food electric power generator plant house at Uwasota (Egor GN), Obey God Bakery (Egor BK), auto mechanic workshop at Uwasota (Egor MW), and auto spare parts shop at Uwelu (Egor SP)

2. Ikpoba Okha local government area-electric power generator plant house at Winner Chapel church, Sapele Road (Ikpoba GN); bakery at Agbor park, Ikpoba Hill (Ikpoba BK); auto mechanic workshop at Aduwawa (Ikpoba MW); and auto spare parts dealer shop around Alohan Filling Station, Sapele Road (Ikpoba SP)

3. Oredo local government area-electric power generator plant house at Stella Obasanjo Hospital, Sapele Road (Oredo GN); bakery near Oba Market, Ring Road (Oredo BK); auto mechanic workshop along Country Home Road, Sapele Road (Oredo MW); and auto spare parts dealer shop along Country Home Road, Sapele Road (Oredo SP)
4. Ovia North East local government area-electric power generator plant house at the Faculty of Life Sciences, UNIBEN (Ovia GN); Efe Bakery, Isiohor (Ovia BK); mechanic workshop at Oluku (Ovia MW); and auto spare parts dealer shop at Oluku (Ovia SP)

Topsoil $(0-10 \mathrm{~cm})$ was randomly collected from the within and around the spill sites and then pooled together to obtain composite samples. Experimental works were done at Jawar Environmental Research Laboratory Limited, Aba, and the Microbiology Laboratory of the Benson Idahosa University, Benin City. About $10 \mathrm{~g}$ of soil was weighed into a $250-\mathrm{ml}$ plastic bottle. One hundred milliliters of $0.1 \mathrm{~m}$ HCI was added, stopped, and then shaken for $30 \mathrm{~min}$. The mixture was filtered through Whitman filter paper No.42. In addition, iron $(\mathrm{Fe})$, manganese $(\mathrm{Mn})$, zinc $(\mathrm{Zn})$, cadmium $(\mathrm{Cd})$, and chromium $(\mathrm{Cr})$ were determined in the filtrate by atomic absorption spectrometry.

Calculation of HQ expresses the possibility of the contaminant being an ecological risk or a contaminant of potential ecological concern $[15,16]$. The HQ was done according to screening benchmark available in Efroymson et al. [12] and was calculated for both ecotoxicities of the various heavy metal fractions in the soil and their toxicity to soil microbial activities and processes. The soil samples were air-dried and sieved through a 2-mm mesh to remove undesirable material. The dilution series for the soil sample was done by transferring $1 \mathrm{~g}$ of the soil to $9 \mathrm{ml}$ of sterile distilled water in sterile glass containers as blank. The glass containers were shaken for $5 \mathrm{~min}$ and were taken as $10^{-1}$ dilution factor, 10 $\mathrm{ml}$ were then transferred from the $10^{-1}$ dilution into another $9 \mathrm{ml}$ blank to obtain a $10^{-2}$ dilution, and the same process of transfer was repeated twice to obtain a dilution factor of $10^{-4}$.

The spread plate method was employed in taking the heterotrophic bacteria counts. One (1) milliliter of the serially diluted portion of $10^{-4}$ of each soil sample was inoculated onto nutrient agar plates for bacteria and Potato dextrose agar plates for fungal counts. The plates were inoculated at room temperature for $24 \mathrm{~h}$ and $72 \mathrm{~h}$ respectively, for bacteria and fungi growth. After incubation, colonies were then counted and the colony-forming unit (CFU/g) of the soil samples determined. Bushnell-Haas medium (Atlas, 1994) was used as the enrichment medium with $8 \%(\mathrm{v} / \mathrm{v})$ filtersterilized oil as the sole carbon source. The medium was dispensed into in 100-ml Erlenmeyer flasks and autoclaved at $121^{\circ} \mathrm{C}$ for $15 \mathrm{~min}$. Thereafter, $5 \mathrm{~g}$ of each soil sample was inoculated into each flask of the medium and incubated at $130 \mathrm{rpm}$ at room temperature in an HY-4 multifunctional shaker (B. Bran Scientific and Instrument Company, England). After 10 days, $1 \mathrm{ml}$ of enriched media was transferred into freshly prepared enrichment media and incubated under the same conditions as described above. Serial dilutions from the third enrichment process were inoculated onto nutrient 
agar plates and potato dextrose agar plates for oil-degrading bacterial and fungal counts respectively. Distinct colonies were counted and sub-cultured to obtain pure colonies which were then stored on slants for further studies. The bacterial isolates were identified using conventional microbiological and biochemical tests as described by Cowan [8] and adopted by Ogwu and Osawaru [23]. The fungal isolates were identified by colonial characteristic and microscopic examination of hyphal morphology as well as by structure and nature of the fruiting body.

The diversity and richness of microorganisms (bacteria and fungi) were calculated using Margalef and Menhinick's indices (species richness), Shannon-Weiner and Simpsons dominant indices (diversity), and species evenness.

\section{Results}

The ecological hazard quotient of the heavy metal composition of spent crude oil-polluted soil within Benin metropolis is presented in Table 1. The HQ of $\mathrm{Cr}, \mathrm{Mn}$, and Fe were highest in auto mechanic workshop from Egor while $\mathrm{Zn}$ was highest in generator plant house from Ovia.

Table 1 Ecological hazard quotient of the heavy metal composition of spent crude oil-polluted soil within Benin metropolis

\begin{tabular}{|c|c|c|c|c|c|}
\hline & ${ }^{\mathrm{a}} \mathrm{Cr}[1]$ & $\mathrm{Mn}$ [100] & $\mathrm{Zn}[50]$ & Fe [200] & $\mathrm{Cd}[4]$ \\
\hline \multicolumn{6}{|c|}{ Soil around generator plant } \\
\hline Egor GN & 1.08 & 0.0352 & 1.8524 & 8.2611 & 0.0015 \\
\hline Ikpoba GN & 1.02 & 0.0056 & 1.3044 & 8.0061 & 0.0075 \\
\hline Oredo GN & 0.09 & 0.0069 & 0.06748 & 6.8121 & $>10^{4}$ \\
\hline Ovia GN & 1.32 & 0.0633 & 4.2216 & 8.16125 & 0.0015 \\
\hline \multicolumn{6}{|c|}{ Soil within auto mechanic workshop } \\
\hline Egor MW & 2.19 & 0.0965 & 4.1108 & 9.32015 & 0.0155 \\
\hline Ikpoba MW & 1.82 & 0.0159 & 3.1172 & 8.2382 & 0.0055 \\
\hline Oredo MW & 0.98 & 0.0109 & 1.1714 & 6.29095 & $>10^{4}$ \\
\hline Ovia MW & 2.10 & 0.0934 & 3.3114 & 6.82615 & 0.0135 \\
\hline \multicolumn{6}{|c|}{ Soil within auto spare parts stores } \\
\hline Egor SP & 1.09 & 0.0698 & 3.7102 & 8.60325 & 0.005 \\
\hline Ikpoba SP & 0.98 & 0.0096 & 1.1964 & 7.81815 & $>10^{4}$ \\
\hline Oredo SP & 0.42 & 0.0038 & 0.539 & 6.52605 & 0.004775 \\
\hline Ovia SP & 0.98 & 0.0098 & 1.2496 & 7.46625 & $>10^{4}$ \\
\hline \multicolumn{6}{|c|}{ Soil around bakery } \\
\hline Egor BK & 0.68 & 0.0105 & 0.125 & $8.152-5$ & $>10^{4}$ \\
\hline Ikpoba BK & 0.28 & 0.0019 & 0.079 & 7.9932 & $>10^{4}$ \\
\hline Oredo BK & 0.49 & 0.0033 & 0.03244 & 6.49105 & $>10^{4}$ \\
\hline Ovia BK & 0.39 & 0.0028 & 0.5934 & 7.41105 & $>10^{4}$ \\
\hline Mean & & & & & \\
\hline
\end{tabular}

Values in bracket are permissible limits [12]

$G N$ electric power generator plant house, $B K$ bakery, $M W$ auto mechanic workshop, $S P$ auto spare parts shop

${ }^{\mathrm{a}}$ Toxic level
The bacterial composition, frequency, and counts from the spent crude oil-polluted soil within Benin metropolis are presented in Table 2 and Appendix. Bacillus substilis and Micrococcus leteus had the highest count (Table 2).

Fungal species composition, count, and frequency recorded from the spent crude oil-polluted soil are presented in Table 3 and Appendix. Highest fungal count was obtained from Ovia MW, and the lowest was recorded from Egor SP. Highest count was recorded from Aspergillus niger.

Bacterial and fungal diversity, richness, evenness, and dominance indices in the different spent crude oilpolluted soil are presented in Table 4. For bacteria, species richness was highest in Egor GN while for fungi it was highest in Oredo GN.

The plant species composition and their frequency found in the spent crude oil oil-polluted soil within Benin metropolis is presented in Table 5.th $=\mathrm{tl} b=$

\section{Discussion}

The petroleum industry has created an economic boom for many countries and at the same time led to environmental and socio-economic problems. Oil-contaminated soils are of environmental concern because they are unsuitable for agricultural and recreational uses and are potential sources for surface and groundwater contamination. Oil-polluted soil could also become unsuitable due to a reduction in the level of available plant nutrients or rise to a toxic level of elements such as manganese [29].

The contamination of soils by heavy metals is a significant problem, which potentially leads to a negative influence on soil characteristics and limitation of productive and environmental functions. Heavy metals affect the number, diversity, and microbial activity of soil microorganisms [6]. They can cause slow down speed of growth and reproduction of microorganisms, in the soil, then prevail slower-growing microorganisms with lower diversity and higher resistance to heavy metals, but decreased biological activity [28].

The results from this study suggest that spent crude oil pollution is reducing the ecological integrity of the city. Heavy metals present in the soil samples include chromium, manganese, zinc, iron, and cadmium. Some of the heavy metals in this study were beyond the detectable limit. Edebiri and Nwanokwale [10] reported that metals present in spent oil are not necessarily the same as those present in the unused lubricants; Whisman et al. (1974) observed that most heavy metals like $\mathrm{V}, \mathrm{Pb}, \mathrm{Al}, \mathrm{Ni}$, and $\mathrm{Fe}$ that are below detection in unused lubricants oil gave high concentration values in used oil. This is similar to the findings of Osawaru et al. [26].

According to Cataldo and Wildung [7], the major factor determining the availability of metal to plants in soils is the solubility of the metal. Moreover, the mobility of heavy metals depends on their chemical forms, which in turn is related to the chemical properties of soil. For 
Table 2 Bacterial count in spent crude oil-polluted sites within Benin metropolis

\begin{tabular}{|c|c|c|c|c|c|c|c|}
\hline & $\begin{array}{l}\text { Ba.sb } \\
\left(\times 10^{5}\right.\end{array}$ & $\begin{array}{l}\text { Sa.sp } \\
\text { cfu/g) }\end{array}$ & Cl.sp & Cl.pe & $M c . s p$ & Mc.lu & Total count \\
\hline Egor GN & 0.23 & 0.58 & 0 & 0.25 & 0 & 0.65 & 171,000 \\
\hline Ikpoba GN & 0.14 & 0 & 0.13 & 0 & 0.19 & 0.51 & 97,000 \\
\hline Oredo GN & 0.12 & 0 & 0.03 & 0 & 0.31 & 0 & 46,000 \\
\hline Ovia GN & 0.25 & 0 & 0.09 & 0.12 & 0.26 & 0 & 72,000 \\
\hline Egor MW & 0.11 & 0 & 0 & 0.28 & 0 & 0.26 & 65,000 \\
\hline Ikpoba MW & 0.23 & 0.43 & 0.14 & 0 & 0.42 & 0 & 122,000 \\
\hline Oredo MW & 0.19 & 0 & 0 & 0 & 0.29 & 0.19 & 67,000 \\
\hline Ovia MW & 0.36 & 0.29 & 0.29 & 0 & 0 & 0.22 & 116,000 \\
\hline Egor SP & 0 & 0 & 0.18 & 0.29 & 0.43 & 0.18 & 108,000 \\
\hline Ikpoba SP & 0.22 & 0 & 0.23 & 0 & 0.33 & 0 & 78,000 \\
\hline Oredo SP & 0.18 & 0.63 & 0.19 & 0 & 0 & 0 & 100,000 \\
\hline Ovia SP & 0.20 & 0.51 & 0 & 0.36 & 0 & 0.42 & 149,000 \\
\hline Egor BK & 0.69 & 0 & 0 & 0.53 & 0 & 0.68 & 190,000 \\
\hline Ikpoba BK & 0.52 & 0 & 0.23 & 0 & 0.29 & 0 & 104,000 \\
\hline Oredo BK & 0.97 & 0.44 & 0 & 0 & 0 & 0.39 & 180,000 \\
\hline Ovia BK & 1.02 & 0 & 0 & 0.16 & 0 & 0.48 & 166,000 \\
\hline Microorg. Total & 5.43 & 2.88 & 1.51 & 1.99 & 2.52 & 3.98 & $1,650,000$ \\
\hline Mean & 0.34 & 0.18 & 0.09 & 0.12 & 0.16 & 0.25 & - \\
\hline Freq. occur. (\%) & 93.75 & 37.50 & 56.25 & 43.75 & 50.00 & 62.50 & \\
\hline
\end{tabular}

Ba.sb Bacillus substilis, Sa.sp Sarcina sp., Cl.sp Clostridium sp., Cl.pe C. perfringens, Mc.sp Micrococcus sp., Mc.lu M. luteus, GN electric power generator plant house, $B K$ bakery, $M W$ auto mechanic workshop, $S P$ auto spare parts shop

example in some types of soil, the presence of carbonate effectively immobilized $\mathrm{Cd}$ and $\mathrm{Cu}$ by providing an adsorbing surface or by buffering the $\mathrm{pH}$ [9]. Therefore, plant roots can absorb heavy metals, which are in turn transferred to other parts of the plant. Animals and other members of the food chain can be contaminated when they consume the plant.

Soil parameters, such as $\mathrm{pH}$, organic carbon content, iron and manganese content, and total metal content, affect the distribution of copper and cadmium between different soil fractions. The mobility of most heavy metals in the soil and subsoil depends on the physicochemical properties of the solid and liquid phases. We observed that there were more heavy metals at the auto mechanic workshop compared to other locations used. This is likely due to the frequent disposal of waste engine oil (WEO) and other petroleum products by automobile engineers especially during repairs and servicing of automobiles. Edebiri and Nwanokwale [10] and Wang et al. (2000) reported that WEO contain toxic amounts of hydrocarbons such as polycyclic aromatic hydrocarbon and heavy metals.

Six bacterial and nine fungal species were found in the spent crude oil-polluted soil in the present study. Common microorganisms found in crude oil-polluted soil around electric power generator plant and auto mechanic workshop are Bacillus subtilis and Aspergillus niger while the most prevalent in auto spare parts stores are Clostridium sp. and Aspergillus niger. Overall, $A$. niger was the most prevalent microorganism present in all the soil samples. The few species of microorganisms recorded from spent crude oilpolluted soil from auto spare parts stores may be due to the limited use of crude oil products around the stores compared to auto mechanic workshop and electric power generator plant house. Importantly, the microorganisms found in this study may have been associated with remediation process, considering the fact that their prevalence, even in higher concentrations of spent crude oil pollution, may signify tolerance to these pollutants. Previously some of the microorganism reported here have been identified as active members of the bioremediation microbial consortia by Cerniglia (1992), Ekundayo and Obuekwe [13], Romero et al. [27], and April et al. [2]. Moreover, Irwin [17] opined that microbial species associated with contaminated site might be implicated in degrading target contaminants or performing important ecosystem functions, which may be enhanced by the introduction of microorganisms known for their bio-remediation capabilities. Certain bacteria belonging to the Bacillus and Pseudomonas species have these desirable characteristics: they consume organic waste thousands of times faster than the types of bacteria that are naturally present in the waste; they grow and reproduce easily, are non-pathogenic, and do not produce foul odors or gas [11]. Fungi have been used in the treatment of waste and wastewaters and the role of fungi in the bioremediation of various hazardous and toxic compounds in soils and sediments have been established. They have also shown the removal of metals and degradation and mineralization of phenols and other phenolic compound, petroleum hydrocarbons, polycyclic aromatic hydrocarbons, polychlorinated biphenyls, chlorinated insecticides and pesticides, and other substances in various matrices. Saprophytic fungi degrade organic matter to release carbon, nitrogen, and other elements locked up in complexes [3]

A total of 22 plant species were recorded from all the spent crude oil-polluted sites. This suggests that these species may have the capacity to accumulate heavy metals in spent crude oil-contaminated soil. However, pollution is likely to affect the distribution and diversity of plants ([24]; Osawaru and Ogwu, 2015). The most common plant species in the soil samples is a known weed species-Eleusine indica. The predominance of Eleusine indica in soil samples in all the sites may suggest that they are the most tolerant to spent engine oil and its heavy metal contents. This phenomenon demonstrates that the family has the highest genetic potential to clean up spent engine oil-contaminated soil.

\section{Conclusion}

In conclusion, the findings from the study suggest the presence of high amounts of heavy metal in 
Table 3 Fungal counts in the spent crude oil-polluted soil within Benin metropolis

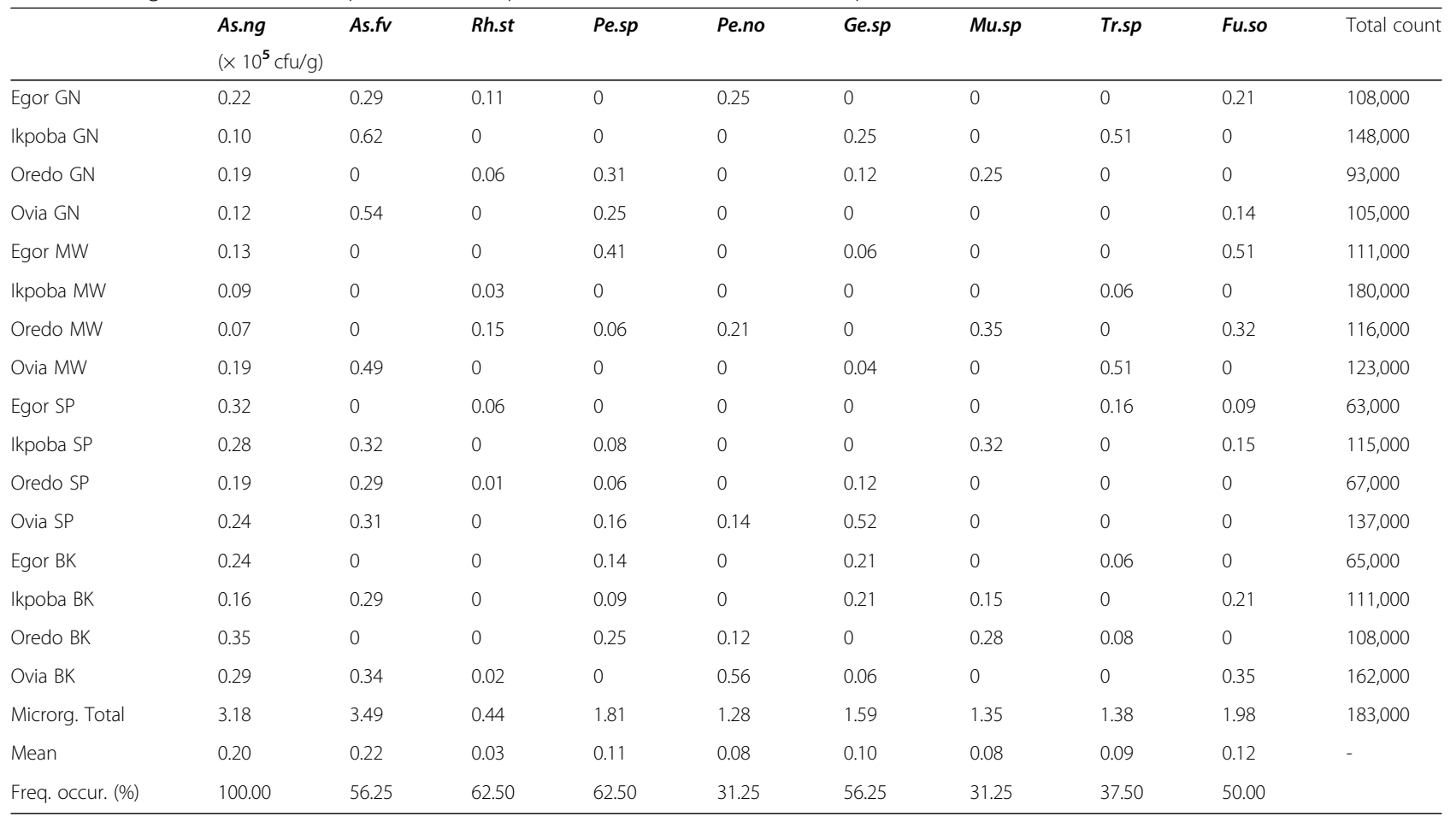

As.ng Aspergillus niger, As.fv A. flavus, Rh.st Rhizopus stolonifer, Pe.sp Penicillium sp., Pe.no P. notatum, Ge.sp Geotrichum sp., Mu.sp Mucor sp., Tr.sp Trichoderma sp., Fu.so Fusarium solani, GN electric power generator plant house, BK bakery, MW auto mechanic workshop, SP auto spare parts shop

spent crude oil-polluted soil. The presence of spent engine oil-contaminated soils. However, furhigher plants and variable diversity and richness of ther studies are required to confirm the effects on microorganisms found in the soil are likely con- and roles of the plant species that are reported in tributing to the remediation of the polluted soil. this study as tolerant to spent crude oil-polluted This may, in turn, reduce the risks associated with soils.

Table 4 Bacterial and fungal diversity, richness, evenness, and dominance indices in the different spent crude oil-polluted soil

\begin{tabular}{|c|c|c|c|c|c|c|c|c|c|c|}
\hline \multirow[b]{2}{*}{ Sources } & \multicolumn{5}{|l|}{ Bacteria } & \multicolumn{5}{|l|}{ Fungi } \\
\hline & Richness $^{\mathbf{a}}$ & Shannon & Evenness & Dominance & Margalef & Richness $^{\mathbf{a}}$ & Shannon & Evenness & Dominance & Margalef \\
\hline Egor GN & 0.3996 & 0.3414 & 0.028 & 0.002611 & 0.244 & 0.26 & 0.281 & 0.024 & 0.000924 & 0.029 \\
\hline Ikpoba GN & 0.2267 & 0.218 & 0.019 & 0.002611 & -0.0103 & 0.3644 & 0.325 & 0.027 & 0.02637 & 0.171 \\
\hline Oredo GN & 0.1075 & 0.054 & 0.005 & 0.0000499 & -0.1857 & 0.589 & 0.246 & 0.022 & 0.000782 & -0.025 \\
\hline Ovia GN & 0.1683 & 0.178 & 0.016 & 0.000458 & -0.0963 & 0.2585 & 0.253 & 0.022 & 0.001425 & 0.018 \\
\hline Egor MW & 0.1519 & 0.155 & 0.014 & 0.000472 & -0.1204 & 0.2733 & 0.18 & 0.015 & 0.001036 & 0.039 \\
\hline Ikpoba MW & 0.2851 & 0.266 & 0.023 & 0.001293 & 0.0757 & 0.443 & 0.06 & 0.006 & 0.00046 & -0.293 \\
\hline Oredo MW & 0.1566 & 0.16 & 0.014 & 0.00061 & -0.1135 & 0.2856 & 0.299 & 0.026 & 0.0011 & 0.057 \\
\hline Ovia MW & 0.2711 & 0.262 & 0.022 & 0.00103 & 0.0550 & 0.3028 & 0.276 & 0.024 & 0.001975 & 0.082 \\
\hline Egor SP & 0.2524 & 0.244 & 0.021 & 0.000994 & 0.0275 & 0.1551 & 0.17 & 0.015 & 0.000513 & -0.132 \\
\hline Ikpoba SP & 0.1823 & 0.831 & 0.074 & 0.000627 & -0.0757 & 0.2831 & 0.29 & 0.025 & 0.001144 & 0.054 \\
\hline Oredo SP & 0.2337 & 0.208 & 0.018 & 0.001459 & 0 & 0.1649 & 0.182 & 0.016 & 0.0005074 & -0.118 \\
\hline Ovia SP & 9.3482 & 0.311 & 0.026 & 0.001809 & 0.1685 & 0.3373 & 0.331 & 0.028 & 0.001721 & 0.132 \\
\hline Egor BK & 0.440 & 0.348 & 0.029 & 0.03632 & 0.3096 & 0.1600 & 0.177 & 0.016 & 0.000457 & -0.125 \\
\hline Ikpoba BK & 0.2430 & 0.222 & 0.019 & 0.001216 & 0.0138 & 0.2733 & 0.362 & 0.031 & 0.00171 & 0.039 \\
\hline Oredo BK & 0.4207 & 0.326 & 0.027 & 0.003828 & 0.2752 & 0.2659 & 0.277 & 0.024 & 0.001042 & 0.029 \\
\hline Ovia BK & 0.3879 & 0.298 & 0.025 & 0.003864 & 0.2270 & 0.3988 & 0.375 & 0.031 & 0.002788 & 0.221 \\
\hline
\end{tabular}

GN electric generator plant house, $B K$ bakery, $M W$ auto mechanic workshop, $S P$ auto spare parts shop 


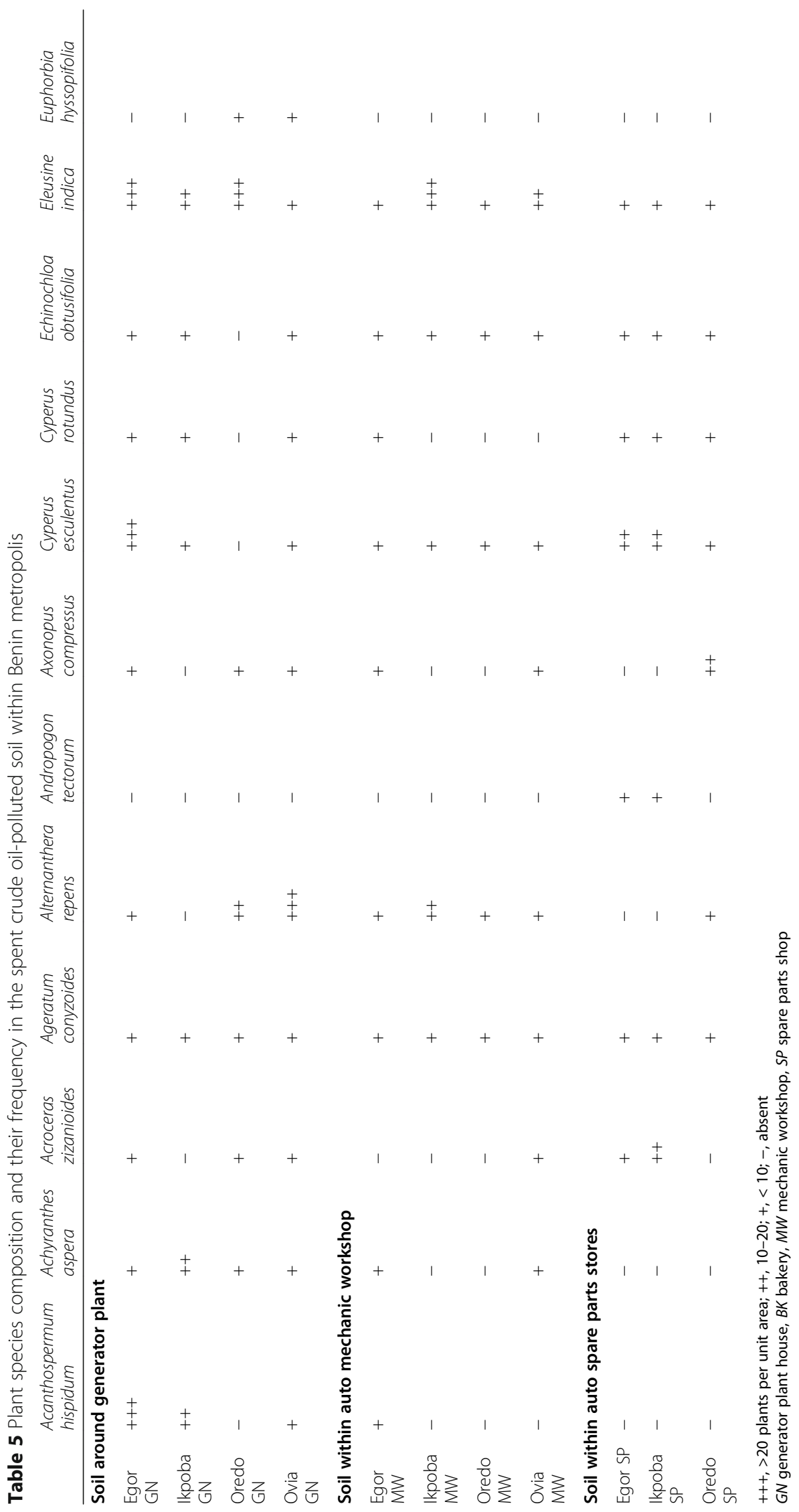




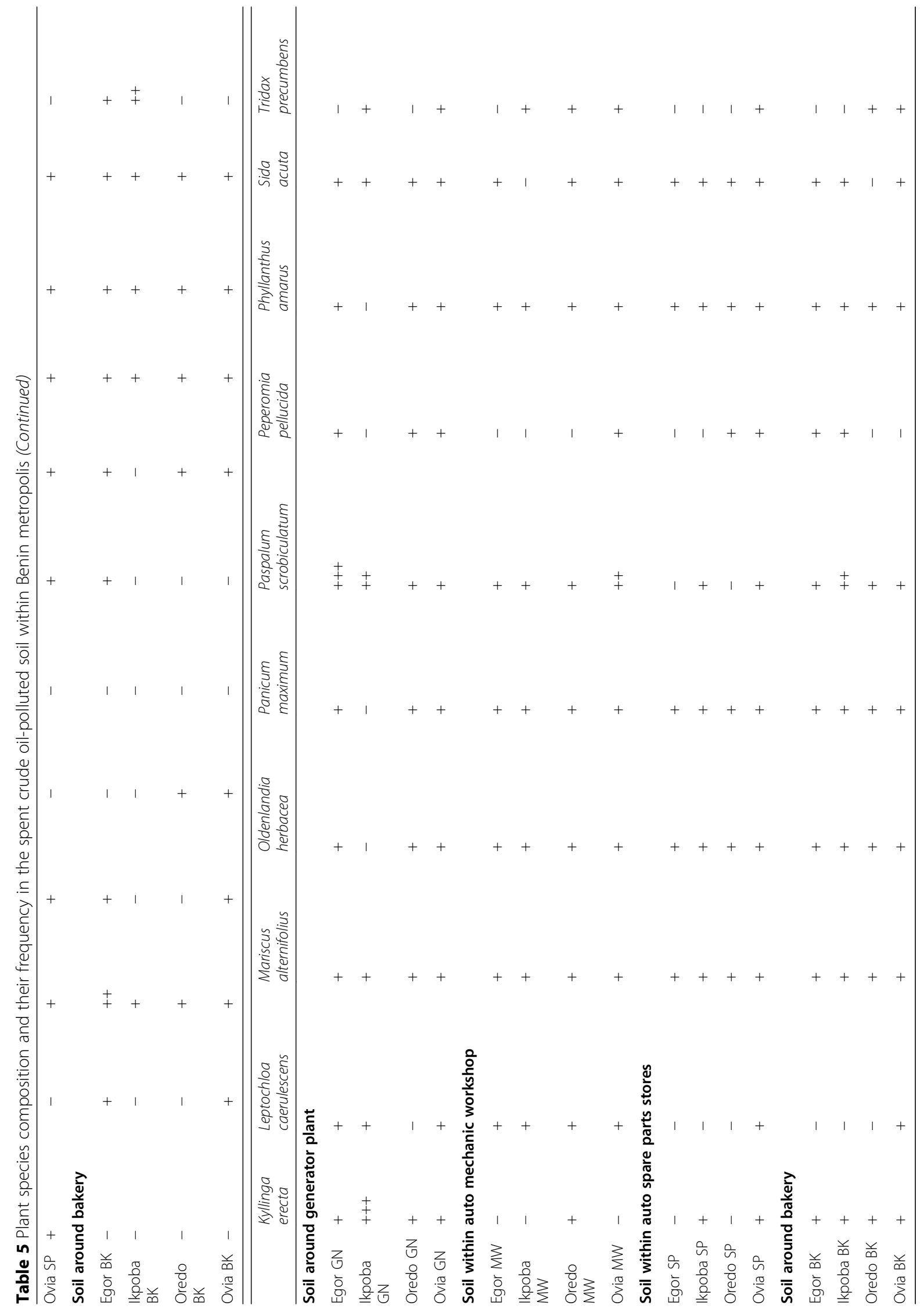




\section{Appendix}

Table 6 Microbial species composition of waste oil-polluted soil collected from designated sites within Benin metropolis to microbial activities and processes

\begin{tabular}{|c|c|c|c|c|c|c|c|c|c|c|c|c|c|c|c|}
\hline & \multicolumn{6}{|c|}{ Bacterial species } & \multicolumn{9}{|c|}{ Fungal species } \\
\hline & Ba.sb & Sa.sp & Cl.sp & Cl.pe & Mc.sp & Mc.lu & As.ng & As.fv & Rh.st & Pe.sp & Pe.no & Ge.sp & Mu.sp & Tr.sp & Fu.so \\
\hline \multicolumn{16}{|c|}{ Soil around generator plant } \\
\hline Egor GN & + & + & - & + & - & + & + & + & + & - & + & - & - & - & + \\
\hline Ikpoba GN & + & - & + & - & + & + & + & + & - & - & - & + & - & + & - \\
\hline Oredo GN & + & - & + & - & + & - & + & - & + & + & - & + & + & - & - \\
\hline Ovia GN & + & - & + & + & + & - & + & + & - & + & - & - & - & - & + \\
\hline \multicolumn{16}{|c|}{ Soil within auto mechanic workshop } \\
\hline Egor MW & + & - & - & + & - & + & + & - & - & + & - & + & - & - & + \\
\hline Ikpoba MW & + & + & + & - & + & - & + & - & + & - & - & - & - & + & - \\
\hline Oredo MW & + & - & - & - & + & + & + & - & + & + & + & - & + & - & + \\
\hline Ovia MW & + & + & + & - & - & + & + & + & - & - & - & + & - & + & - \\
\hline \multicolumn{16}{|c|}{ Soil within auto spare parts stores } \\
\hline Egor SP & - & - & + & + & + & + & + & - & + & - & - & - & - & + & + \\
\hline Ikpoba SP & + & - & + & - & + & - & + & + & - & + & - & - & + & - & + \\
\hline Oredo SP & + & + & + & - & - & - & + & + & + & + & - & + & - & - & - \\
\hline Ovia SP & + & + & - & + & - & + & + & + & - & + & + & + & - & - & - \\
\hline \multicolumn{16}{|c|}{ Soil around bakery } \\
\hline Egor BK & + & - & - & + & - & + & + & - & - & + & - & + & - & + & - \\
\hline Ikpoba BK & + & - & + & - & + & - & + & + & - & + & - & + & + & - & + \\
\hline Oredo BK & + & + & - & - & - & + & + & - & - & + & + & - & + & + & - \\
\hline Ovia BK & + & - & - & + & - & + & + & + & + & - & + & + & - & - & + \\
\hline Freq. Occ. (\%) & 93.75 & 37.50 & 56.25 & 43.75 & 50.00 & 62.50 & 100.00 & 56.25 & 62.50 & 62.50 & 31.25 & 56.25 & 31.25 & 37.50 & 50.00 \\
\hline
\end{tabular}

Freq. Occ. (\%), frequency of occurrence of microorganism; -, absent;+, present; Ba.sb, Bacillus substilis; Sa.sp, Sarcina sp.; Cl.sp, Clostridium sp.; Cl.pe, C. perfringens; Mc.sp, Micrococcus sp.; Mc.lu, M. luteus; As.ng, Aspergillus niger; As.fv, A. flavus; Rh.st, Rhizopus stolonifer; Pe.sp, Penicillium sp.; Pe.no, P. notatum; Ge.sp, Geotrichum sp.; Mu.sp, Mucor sp.; Tr.sp, Trichoderma sp.; Fu.so, Fusarium solani; GN, generator plant house; BK, bakery; MW, mechanic workshop; SP, spare parts shop

\section{Abbreviations}

LGA: Local government area; MW: Mechanic workshop; BK: Bakeries; GN: Power generating house; SP: Auto spare part dealer shops; THC: Total hydrocarbon content; Fe: Iron; Cu: Copper; Mn: Manganese; Zn: Zinc; Cr: Chromium; Pb: Lead; Ni: Nickel; Cd: Cadmium; HQ: Hazard quotient; pH: Hydroxyl ion; BH: Bushnell-Haas; CFU/g: Colony-forming unit per gram

\section{Acknowledgements}

The authors are grateful for the support and motivation of the management of the University of Benin, Nigeria.

\section{Authors' contributions}

There is equal contribution in the design of the experiment, sampling, data analysis, and manuscript preparation. The authors contributed equally to the work, and both reviewed and accepted the final version of the manuscript.

\section{Funding}

This work was supported by the private funds of the authors

\section{Availability of data and materials}

Not applicable.

Ethics approval and consent to participate Not applicable.

\section{Consent for publication}

Not applicable.

\section{Competing interests}

There are no competing interests both financial and otherwise. The authors declare no conflict of interests.

Received: 10 January 2020 Accepted: 29 April 2020

Published online: 08 July 2020

\section{References}

1. Anoliefo GO, Vwioko DE (2001) Tolerance of Chromolema odorota (L.) K and R grown in soil contaminated with spent lubricant oil. J Crop Biosci 1:20-24

2. April TM, Foght JM, Currah RS (2000) Hydrocarbon-degrading filamentous fungi isolated from flare pit soils in northern and Western Canada. Can $J$ Microbiol 46(1):38-49

3. Atlas RM (1995) Petroleum biodegradation and oil spill bioremediation. Mar Pollut Bull 31:178-182

4. Atuanya EJ (1987) Effect of oil pollution on physical and chemical properties of soil: a case study of waste oil contaminated delta soil in Bendel state, Nigeria. J Appl Sci 55:155-176

5. Braddock JF, Ruth ML, Catterall PH (1997) Enhancement and inhibition of microbial activity in hydrocarbon-contaminated artic solis: implications for nutrient-amended bioremediation. Environ Sci Technol 31:2078-2083 
6. Castaldi S, Rutigliano FA, Virzo De Santo A (2004) Suitability of soil microbial parameters as indicators of heavy metal pollution. Water Air Soil Pollut 58: $121-135$

7. Cataldo DA, Wildung RE (1978) Soil and plant factors influencing the accumulation of heavy metals by plants. Environ Health Perspective 27:149159

8. Cowan ST (1974) Cowan and Steel's manual for the identification of medical bacteria, 2nd edn. Cambridge University Press, Cambridge, pp 67-83

9. Dudley LM, McLean JE, Furst TH, Jurinak JJ (1991) Sorption of cadmium and copper from an acid mine waste extract by two calcareous soils: column study. Soil Sci 151(2):121-135

10. Edebiri, R.A.O. and Nwanokwale, E. (1981). Control of pollution from internal combustion engine used lubricant. Proceedings of the International Seminar Petroleum Industry and the Nigeria Environment. 12 pp.

11. Efeovbokhan VE, Hymore FK, Oyakhire CTG (2012) The effects of Pseudomonas aeroginosa and Aspergillus niger on the bioremediation of raw and treated crude oil polluted water. Int J Sci Technol 2(6):2224-3577

12. Efroymson RA, Suter GW II, Sample BE, Jones DS (1997) Preliminary remediation goals for ecological endpoints. US DoE and Lockheed Martin energy systems. Inc, East Tennessee, USA, $41 \mathrm{p}$

13. Ekundayo EO, Obuekwe CA (1997) Effects of oil spill on soil physicochemical properties of a spill site in a typical edult of Midwestern Nigeria. Environ Pollut 22:187-196

14. Igwe JC, Abia AA, Ibeh CA (2008) Adsorption kinetics and Intraparticulate diffusivities of hg, as, and $\mathrm{Pb}$ ions on unmodified and thiolated coconut fibre. Int J Environ Sci Technol 5:83-92

15. Ikhajiagbe B (2010) Synergism in bioremediation: phytoassessment of waste engine oil polluted soils after amendment and bioaugmentation. Lap lambert academic publishing. Köln, Germany

16. Ikhajiagbe B, Anoliefo GO (2010) Impact of soil amendment on phytotoxicity of a 5-months old waste engine oil polluted soil. J Ecol Nat Environ 2(6):112-122

17. Irwin P (1996) To clean up environmental spill, know your medium. Electrical World 8:37-40

18. Ivshina IB, Kuyukina MS, Krikoruchko AV, Elkin AA, Makarov SO, Cunningham CJ, Peshkur TA, Atlas RM, Philp JC (2015) Oil spill problems and sustainable response strategies through new technologies. Environ Sci Processes Impact 17:1201

19. Jain PK, Gupta VK, Gaur RK, Lowry M, Jaroli DP, Chauhan UK (2009) Bioremediation of petroleum oil contaminated soil and water. Res J Environ Toxic 5(1):1-26

20. National Research Council (US) Committee on Oil in the sea: inputs, fates, and effects. Oil in the sea III: inputs, fates, and effects. Washington (DC): National Academies Press (US); 2003. Executive Summary. Available from: https://www.ncbi.nlm.nih.gov/books/NBK220701/

21. Nriagu J, Udofia EA, Ekong I, Ebuk G (2016) Health risks associated with oil pollution in the Niger Delta, Nigeria. Int J Environ Res Public Health 13(3): 346. https://doi.org/10.3390/ijerph13030346

22. Odjegba VJ, Sadiq AO (2002) Effect of spent engine oil on the growth parameters, chlorophyll and protein levels of Amaranthus hybridus. Environmentalist 22:23-28

23. Ogwu MC, Osawaru ME (2014) Comparative study of microflora population on the phylloplane of common okra [Abelmoschus esculentus I. (Moench.)]. Nigerian J Biotechnol 28:17-25

24. Ogwu MC, Osawaru ME, Ahana CM (2014) Challenges in conserving and utilizing plant genetic resources (PGR). Int J Genetics Mol Biol 6(2):16-22. https://doi.org/10.5897/IJGMB2013.0083

25. Osawaru, M.E., Ogwu M. C, and Chime, A. O. (2013b). Assessment of growth performance of two cultivated okra species (Abelmoschus esculentus (L.)) Moench and Abelmoschus caillei (a. Chev.) Stevels) exposed to crude oil contaminated soil. Nigerian J Biotechnol, 26, 11 - 20

26. Osawaru, M.E., Ogwu, M.C. and Braimah, L. (2013a). Growth responses of two cultivated okra species (Abelmoschus caillei (A. Chev) Stevels and Abelmoschus esculentus (Linn.) Moench) in crude oil contaminated soil. Nigerian Journal of Basic and Applied Science, 21(3), 215 - 226. DOI: Ihttp:// dx.doi.org/https://doi.org/10.4314/njbas.v21i3.7

27. Romero MC, Hammer E, Cazau MC, Arambarri AM (2001) Selection of autochthonous yeast strains able to degrade biphenyl. Word J Microbio Biotechnol 17:591-594

28. Šimon T (1999) The effect of increasing rates of nickel and arsenic on the growth of radish and soil microflora. Rostlinna Vyroba 45:421-430
29. Udo EJ, Fayemi AAA (1975) The effect of oil pollution on germination growth and nutrient uptake of corn. J Environ Qual 4:537-540

30. Vazquez-Duhalt R, Bartha R (1989) Biodegradation of petroleum in soil environment. Can J Microbiol 20:1985-1988

31. Vwioko DE, Anoliefo GO, Fashemi SD (2006) Metals concentration in plant tissues of Ricinus communis L. (Castor oil) grown in soil contaminated with spent lubricant oil. J Appl Sci Environ Manag 10:127-134

32. Vwioko DE, Okoekhian I, Ogwu MC (2018) Stress analysis of Amaranthus hybridus L. and Lycopersicon esculentum mill. Exposed to Sulphur and nitrogen dioxide. Pertanika J Trop Agric Sc 41(3):1169-1191

\section{Publisher's Note}

Springer Nature remains neutral with regard to jurisdictional claims in published maps and institutional affiliations.

\section{Submit your manuscript to a SpringerOpen ${ }^{\circ}$ journal and benefit from:}

- Convenient online submission

- Rigorous peer review

- Open access: articles freely available online

- High visibility within the field

- Retaining the copyright to your article

Submit your next manuscript at $\boldsymbol{\nabla}$ springeropen.com 